\title{
Belajar Memperjuangkan Kebersamaan di Negeri Syariat : Studi "Life History" Strategi Adaptasi Mahasiswi non Muslim Universitas Malikussaleh
}

\author{
Rizki Istiqomah \\ Prodi Antropologi FISIP Universitas Malikussaleh
}

\begin{abstract}
Abstrak
Artikel ini melihat strategi adaptasi mahasiswi Non Muslim di Universitas Malikussaleh Lhokeumawe di linkungan syari'at Islam, Aceh. Fokus pembahasan melihat pengalaman keseharian mahasiswi non-muslim di Universitas Malikussaleh dalam berinteraksi dengan muslim di Aceh dan kehidupan sosial di lingkungan syariat Islam. Metode yang digunkan dalam penelitian ini adalah studi kasus yang memusatkan diri secara insentif terhadap sutu objek tertentu dengan mempelajari sebagai sutu kasus. Penelitian ini menggunakan pendekatan life history dimana data yang digunakan berasal dari pengalaman-pengalaman individu masyarakat dan pengalaman individu tersebut nanti akan digunakan untuk menggambarkan keadaan masyarakat yang akan diteliti terutama yang terkenan dengan permasalahan penelitian. Subjek penelitian adalah mahasiswi non Muslim di Universitas Malikussaleh. Hasil penelitian ini menunjukkan mahasiswi non muslim dalam pengalaman berdaptasi awalnya mahasiswi non Muslim ada perasan takut menetap di daerah perantaun Lhokseumawe, Aceh. Dalam strategi adaptasi mahasiswi Non Muslim melakukan penyesuaian diri, dengan menghormati keyakinan dari budaya lain. Berpakaian sopan seperti aturan yang telah ditentukan syariat Islam merupakan bentuk penghormatan tersebut. Mahasiswi Non Muslim beradaptasi dengan lingkungan sekitar dan tetap melakukan kebiasaan- kebiasaan, praktik-praktik dan tradisi-tradisi mereka di tempat baru mereka beradaptasi, agar tetatp terjaga kebudayaan mereka. Hal ini ternyata membantu mereka dalam menempatkan diri sesuai dengan situasi dan kondisi dimana mereka berinteraksi dan bagaimana harus bersikap sehingga dapat menbangun kebersamaan antar keyakinan dan antarbudaya yang efektif.
\end{abstract}

Kata Kunci: Adaptasi, Non-Muslim, Syariat Islam, Aceh 


\section{Pendahuluan}

Penyesuain diri merupakan salah satu faktor yang sangat penting dalam kehidupan manusia, apalagi pada saat individu memasuki bangku pekuliahan. Permasalahan mahasiswa baru saat memasuki masa perkuliahan berpariasi, mulai dari permasalahan yang sifatnya pribadi, permasalahan akademik ataupun relasi interpersonal. Seorang mahasiswa baru harus menyesuaikan diri dengan lingkungan barunya mulai dari materi perkuliahan, proses belajar, teman baru, jadwal perkuliahan, atau aturanaturan yang berlaku.

Sebagai pendatang harus menyesuaikan diri dengan lingkungan setempat. Interaksi akan berjalan baik bila mampu beradaptasi mengurangi gesekan nilai dan kebiasaan yang berlaku pada masyarakat yang telah lama tinggal di derah itu, yaitu dengan cara berinteraksi, cepat bergaul, bersikap sopan santun, ramah, berkomunikasi memahami dan menghargai nilai dan kebiasaan masyarakat setempat. Hal ini dimaksud agar tidak terjadi kesalahpahaman dalam pergaulan diantara mereka. Apa yang dianggap baik belum tentu dapat diterima dan dianggap baik dan sopan oleh masyarakat setempat.

Pengalaman mahasiswi non muslim yang memiliki kepercayaan dan budaya yang berbeda untuk melanjutkan pendidikan di Universitas Malikussaleh. Bagaimana kita harus mengetahui berbagai macam karakter dan pola pikir yang berbeda pula. Di mana Aceh merupakan suatu daerah yang sangat kental dengan agama Islam, dan bisa saja menjadi permasalahn utama yang sulit bagi masyarakat pendatang yang non muslim, tidak hanya masalah agama, tetapi juga masalah budaya yang berbeda. Kondisi ini mengharuskan mahasiswi non-muslim harus dapat beradaptasi dengan lingkungan

Dalam beradaptasi, manusia menggunakan kebudayaan sebagai pedoman. Bennet, (Dalam Winata: 2008) proses adaptasi merupakan mekanisme pergaulan yang dimanfaatkan manusia sepanjang kehidupannya, tunduk pada inteprestasi yang berdasrkan nilai sosial. Penyesuaian diri mahasiswa sangat penting untuk menunjang keberlangsungan hidup dalam berinteraksi soaial dengan masyarakat di lingkungan sekitar tempat tinggal (Winata, 2008). Proses adaptasi mahasiswi non-muslim Universitas Malikussaleh menjadi penting dalam membangun interaksi denga lingkungan sosial dengan masyarakat di lingkungannya. 
Beberapa penelitian menjelaskan mengenai adaptasi salah satunya adalah dalam penelitian skripsi Delfi Andri (2015) Prodi Komunikasi Fakultas IImu Sosial IImu Politik Universitas Malikussaleh dari hasil penelitian ini yang berjudul "Komunikasi Antar Budaya Mahasiswa eits Batak" menyimpulkan bahwa peran identitas antar budaya melalui bahasa, agama dan kekerabatan yang dilakukan oleh mahasiswa etnis Batak belum sepenuhnya sesuai dengan peran yang semestinya harus dilakukan di lingkungan Universitas Malikussaleh.

Hubungan atau persamaan penelitian yang dilakukan oleh Delfi Andri dengan penelitian yang akan oleh penulis sama-sama meneliti tentang mahasiswa non muslim dengan berbeda etnik, sama-sama menggunakan penelitian metode Kualitatif. Namun perbedaannya dalam penelitian Delfi Andri memfokuskan tentang komunikasi antarbudaya dengan teori identitas sosial melali bahasa, agama, dan kekerabatan. Dan penelitian yang akan dilakukan, lebih memfokuskan cara mempraktekan adaptasi melalaui agama dan, dan budaya.

Kemudian penelitian (Mumpuni 2015), yang terdapat pada jurnal yang berjudul: "Memahami Adaptasi Budaya Pada Pelajar Indonesia yang Sedang Belajar di Luar Negeri" Jurusan IImu Komunikasi Fakultas IImu Sosial dan IImu Politik Universitas Diponogoro Semarang, menyimpulkan bahwa pelajar Indonesia yang berpindah ke luar negeri untuk belajar akan mengalami perubahan kultural yang cukup besar yang membuat dirinya mendapat tekanan sehingga menyebabkan culture shock. Strategi yang dilakukan untuk beradaptasi antara lain mencari sesuatu yang baik atas apa yang terjadi (positive reinterpretation), mengerjakan aktivitas lain agar melelpas beban pikiran (mentaldisangagement), merelakan sesuatu yang diinginkan (behavioral disengagement), dukungan sosial, serta penerimaan. Pelajar Indonesia juga melakukan adaptasi dengan strategi konvergensi yaitu dengan menyesuaikan perilaku komunikasi sesuai dengan host culture. Selain strategi tersebut, kemampuan seseorang menghadapi fase-fase culture shock tergantung pada tingkat perbedaan kultural dan potensi individu masing-masing. Semakin besar perbedaan kultural dan bahasa maka perlu waktu lebih lama untuk beradaptasi. Seseorang dengan pengetahuan budaya, keterampilan sosial, serta kopetensi antarbudaya mampu menyesuaikan diri dengan lebih cepat. Selain itu lingkungan juga 
ikut mendukung proses adaptasi pelajar, khususnya teman selama di host country.

Wiseman menyebutkan bahwa adaptasi merupakan tujuan hidup yang mendasar dan seseorang berbuat serta menyesuaikan diri sebagai suatu keberanian mengahadapi tantangan lingkungan. Demikian halnya adaptasi merupakan sutu proses yang kompleks dan dinamis. Lingkungan dan manusia berinteraksi secara terus menerus memberikan dan menerima adaptasi dan harus memahami sebagai sebuah fenomena yang muldimensi dan beragam. Seseorang yang hidup di masyarakat baru ia kenal mempunyai tantangan yang beragam baik secara bahasa, sikap masyarakat, sistem keoercayaan, serta budaya yang sangat berbeda dengan budaya sebelumnya (Usman, 2009:32).

\section{Metode Penelitian}

Lokasi penelitian dalam artikel ini di Kota Lhoksemawe, dikerenakan adanya pertambahan jumlah mahasiswa non muslim di Universitas Malikussaleh. Dari fenomena tersebut artikel melihat proses adaptasi mahasiswi non muslim menjalani keseharian di Universitas Malikussaleh dan lingkungan di luar yang masyarakatnya bermayoritas beargama Islam. Artikel menggunakan pendekatan life history. Pendekatan dekstriftif yang berbasis pada studi kasus yang menyangkut dengan adaptasi sosial mempengaruhi alur tulisan. Informan dalam artikel adalah mahasiswi non muslim yang berbeda kultur dan agama yang kuliah di Universitas Malikussaleh, yaitu: Januari Cristin K Yaung, Fitri Andriana Simbolon, Yovita Carolin Surbakti, Lastri Sirait, Yulika Lumban Tobing. Lalu untuk mendukung narasi informan, penulis juga mewawancarai staff administrasi Universitas Malikussaleh dan pemerintah gampong Bathupat, Lhoksemawe. Observasi dilakukan terhadap mahasiswa non muslim tentang cara mereka beradaptasi di lingkungan tempat tinggal dan lingkungan kampus. Pengamatan ini dilakukan pada siang hari di lingkungan kampus Universitas Malikussaleh, dimana mahasiswa non muslim masih dalam kegiatan beraktivitas di dalam kampus. Selain pengamatan di dalam kampus, peneliti mengamati tempat tinggal mahasiswa non muslim di Batuphat.

\section{Hasil dan Pembahasan Gambaran Umum Lokasi}

Mahasiswa non muslim mempunyai kelompok di Lhokseumawe, dengan nama HMKL. Sejarah dimulai ketika beberapa mahasiswa Universitas 
Malikussaleh dipimpin Charles Sihombing (Mahasiswa IImu Politik Universitas Malikussaleh tahun 2008) berencana membentuk suatu wadah perkumpulan mahasiswa di kota Lhokseumawe sekitar tahun 2010, dimana keanggotaannya masih diantara mahasiswa Unimal yang sedang menjalani masa perkuliahan pada saat itu. Pada saat itu, Charles Sihombing dan mahasiswa/i lainnya berniat membentuk persekutuan kristiani tersebut dan berusaha membangun persekutuan tersebut untuk menjadi cabang/ bagian dari Gerakan Mahasiswa Kristen Indonesia (GMKI).

Dari jumlah keseluruhan mahasiswa Aktif angkatan 2015-2017 sebanyak 6724 mahasiswa, terdapat mahasiswa non Muslim di Univerrsitas Malikussaleh. Mahasiswa non muslim angkatan 2015-2017 di Universitas Malikussaleh sebanyak 101 mahasiswa dari berbagai fakultas dan jurusan di Universitas Malikussalehh. Mahasiswa non muslim yang kuliah di Uiversitas Malikussaleh tinggal di Batuphat Barat dan Batupat Timur, mereka beribadah di Gedung Arun PJKP (Persekutuan Jamaat Krisrten Protestan). Di Lhokseumawe mahasiswa non muslim memiliki komonitas yang bernama HMKL (Himpunan Mahasiswa Kristen Lhokseumwe). Mahasiswa non muslim yang kuliah di Universitas Malikussaleh beragama Kristen Protestan, yang masing dari suku batak, dengan marga yang berbeda.

Dari data diatas menunjukan data keseluruhan mahasiswa non Muslim menurut keseluruhan fakultas di Universitas Malikssaleh. Ada sebanyak 101 jumlah mahasiswa non muslim dengan jumlah keseluruhan mahasiswa/i aktif di tahun 2015-2017 sebanyak 6724 mahasiswa, dari jumlah keseluruhan tersebut jumlah persentase mahasiswa non muslim Universitas Malikussaleh di tahun 2015-2017 sebanyak 1,50\%. Jumlah Mahasiswi non muslim Universitas Malikussaleh setiap tahunya meningkat 0,06 \%. 


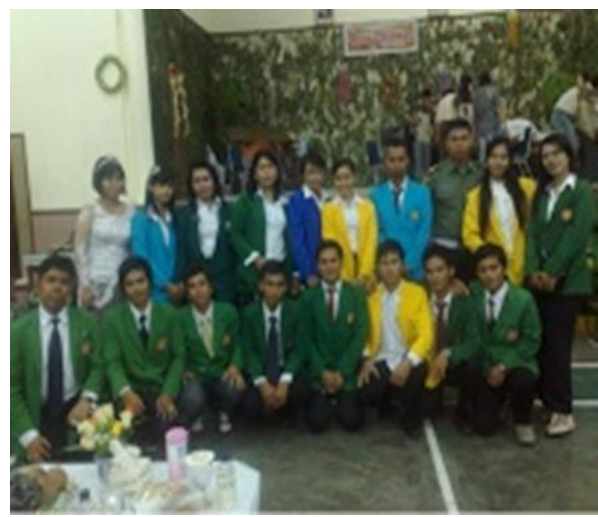

(Sumber: Dokumen HMKL Melaksanan Latihan Panduan Suara Di Gereja, 2012)

Gambar 4.9. Himpunan Mahasiswa Kristen Lhoksumawe, 2012)

Gambar 4.9. Menunjukkan mahasiswa non muslim sedang berfoto bersama usai mengikuti panduan suara untuk mengisi acara natal TNI/Polri yang diadakan pada tahun 2011 di gereja HKBP Lhokseumawe. Digambar tersebut mahasiswa dari Universitas Malikussaleh, mahasiswa Politeknik Negeri Lhokseumawe dan mahasiswa Universitas Samudra Langsa, sebagai tamu untuk ikut serta dalam mengisi acara natal TNI/Polri di Gereja HMKL Lhokseumawe. Mahasiswa non muslim yang berlatih paduan suara dipandu oleh TNI/Polri dan dilatih oleh sintua Gereja HKBP. Mahasiwa pada gambar di atas baru pertama kalinya merayakan Natal dan dimintai sebagai peserta sebagai panduan suara di Lhokseumawe.

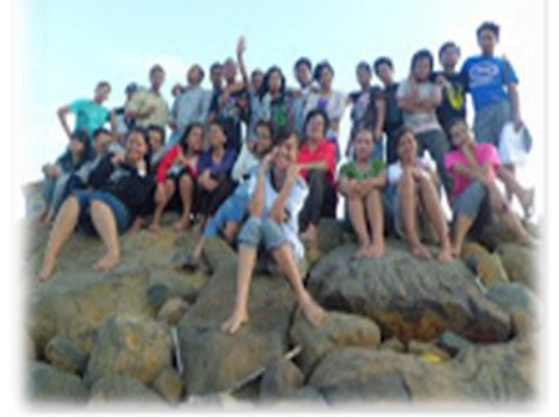

(Sumber: Dokumen Mahasiswa non Muslim Berkumpul dalam Liburan

Bersama di Pantai Rancong, Lhokseumawe, 30 April 2017)

Gambar 4.10. Aktivitas Mahasiswa non Muslim di Pantai Rancong Lhokseumawe, 2017 
Gambar 4.10. Menunjukkan perkumpulan mahasiwa non Muslim Universitas Malikussaleh sedang berlibur di pantai Rancong, Lhokseumawe pada tanggal 30 April 2017. Perkumpulan tersebut dibuat dengan maksud berlibur, dan berkumpul bersenang-senang bersama. Kegembiraan bersama yang dilakukan oleh mahasiswa non muslim yang berada di Lhokseumawe, dimaksudkan agar kekompakan, dan persaudara semakin erat. Mahasiswa non muslim yang berada di Lhokseumawe tidak hanya berkumpul di lingkungan tempat tinggal, tetapi juga berkumpul di tempat rekreasi seperti panti jika ada waktu luang.

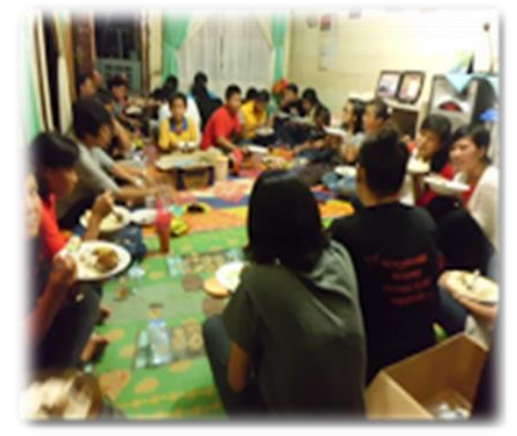

(Sumber: Dokumen Mahasiswa non Muslim Universitas Malikussaleh, Kumpul bersama membentuk HMKL 14 September 2012)

Gambar 4.11. Kekerabatan Mahasisiwa non Muslim

Gambar 4.11. Menggambarkan mahasiswa non muslim sedang berkumpul dan makan malam bersama di rumah bapak I Nehe, di Batuphat Barat. Perkumpulan tersebut dibuat dengan maksud ingin mempersatukan tali persaudaraan dalam sebuah wadah organisasi. Perkumpulan tersebut membincangkan himpunan yang diberi nama Himpunan Mahasiswa Kristen Lhokseumawe. Perkumpulan untuk membentuk himpunan ini dilaksanakan pada tanggal 14 September 2012 di malam hari. Pada tanggal dan malam yang sama telah resmi pembentukan Himpunan Mahasiswa Kristen Lhokseumawe, dan juga telah terpilih ketua, wakil ketua sekretaris, bendahara, dan seksi-seksi lainnya. 


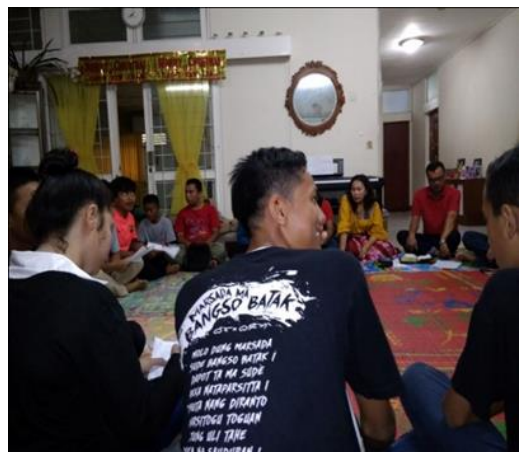

(Sumber: Dokumen gabungan RNHKBP Lhokseumawe, 10 Juni 2017) Gambar 4.12. Gabungan RNHKBP Lhokseumawe

Gambar 4.12. Menunjukkan mahasiswa non muslim menggadakan kumpulan kebaktian pemuda non mon muslim Lhokseumawe. Perkumpulan tersebut dilaksanakan di Lhokseumawe. Di dalam perkumpulan tersebut tampak mahasisawa non muslim sedang berbincang. Perkumpulan tersebut dilaksanakan pada malam hari ada tanggal 10 Juni 2017, perkumpulan yang di laksanakan pada malam hari dikarenakan terbatasnya waktu karena aktivitas yang dilakukan di siang hari. Perkumpulan tersebut mempunyai maksud untuk mempererat tali persaudaran para pemuda umat Kristiani di Lhokseumawe.

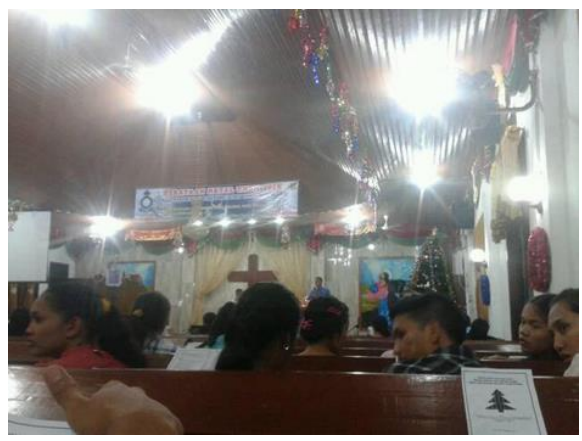

(Sumber: Dokumen Natal di HKBP Resor Lhokseumawe, 10 Desember 2016)

Gambar 4.13 Natal HKBP, resort Lhokseumawe

Gambar 4.13. Menunjukkan mahasiswa non muslim ikut serta dalam perayaan natal di Gereja HKBP Lhokseumawe pada tanggal 10 Desember 2016. Mahasiswa non muslim merayakan natal di Lhokseumawe karena sebagian mahasiswa tidak pulang ke daerah asal. Mahasiswa non muslim Lhokseumawe memilih merayakan natal di Lhokseumawe dikarenakan tidak ada waktu libur kuliah untuk pulang ke daerah asal dan merayakannya di 
daerah asal. Mereka merayakan dengan rasa sedih dibalut dengan rasa gembira. Seperti yang disampaikan oleh Lastri Sirait, mahasiswi non muslim jurusan Manajemen fakultas Ekonomi kepada peneliti:

“ Natal gak pulang kak, pulangnya kalau libur semester sama puaja aja. Natalnya di sini di gereja HKBP Lhoksemawe, sama di gereja PJKP Arun. Mau gak mau lah kak, gada libur kuliah jadinya ya di sini aja senangnya karena ada kawan juga yang natal di sini, sedihnya karena gak natal bareng keluarga" (Wawancara 25 April 2017)

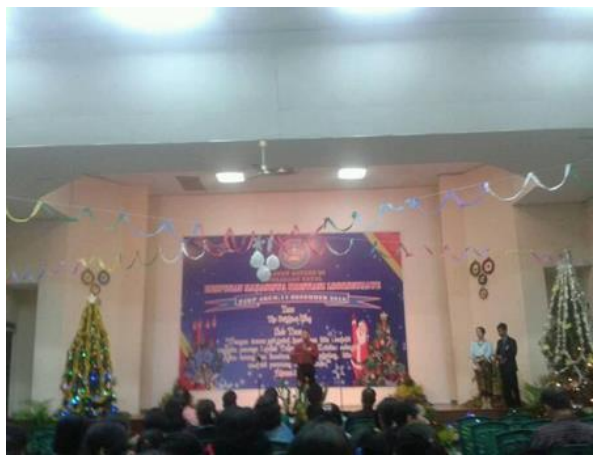

(Sumber: Dokumentasi Natal di Gereja PJKP PT. Arun 11 Desember 2017 Gambar 4.14. Natal di Gereja PJKP PT. Arun

Gambar 4.14. Menunjukkan mahasiswa non muslim dan umat Kristiani yang berada di Bhatupat merayakan natal di gereja PJKP PT. Arun Lhokseumawe pada tanggal 11 Desember 2017. Mereka merayakan natal di gereja PJKP PT. Arun setelah merayakan natal di gereja HKBP Lhokseumae pada tanggal 10 Desember 2016. Maksud dari gambar di atas memeriahkan hari natal di negeri syari'ah, dengan menjalani dengan rasa saling menghormati.

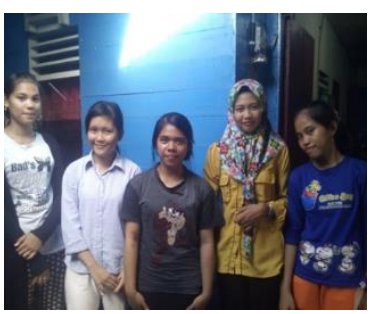

(Sumber, Dokumen Pribadi, 12 Mei 2017)

Gambar 4.15. Peneliti Bersama Informan Di Depan Tempat Tinggal Informan

Gambar 4.15. Menunjukkan suasana di rumah informan, atau di rumah mahasiswi non muslim yang berada di Batuphat Barat. Gambar tersebut 
menjelaskan tentang peneliti sedang berfoto bersama, setalah wawancara dengan sebagian informan atau mahasiswi non muslim. Berada di rumah informan nyaman, karena tata krama, dan dianggap seperti teman dekat, yang menjadi alasan peneliti tidak segan untuk berkunjung di tempat tinggal mahasiswa non muslim.

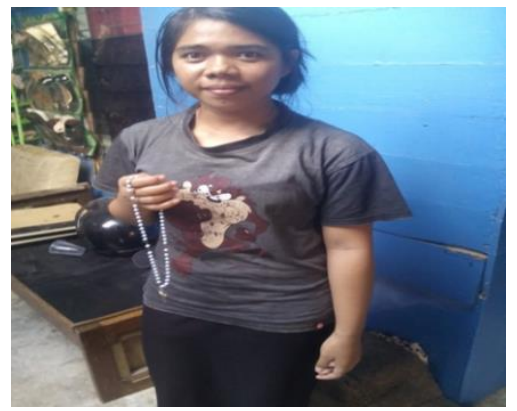

Gambar 4.16. Mahasiswi non Muslim Menunjukkan Kalung Salip Miliknya

(Sumber: Dokumen Pribadi,12 Mei 2017 )

Gambar 4.16. Menunjukkan mahasiswi non muslim memperlihatkan kalung salib yang dimilikinya pada tanggal 12 Mei 2017 kepada peneliti. Kalung salib tersebut dipercayainya sebagai pelindung, karena banyak bacaan-bacaan doa di dalam kalung salib yang informan pegang atau yang ia tunjukkan. Kalung salib tersebut selalu disimpan dan dijaga kemana pun ia tinggal. Di dalam gambar tersebut informan dengan bangga menunjukkan kepunyaannya atau keyakinannya kepada peneliti.

\section{Sejarah Hidup Beberapa Mahasiswa Non Muslim di Universitas Malikussaleh}

Januari Cristin K. Yaung: Gadis Timur di Tanah Rencong

Januari Cristin K. Yaung lahir pada tanggal 03 Januari 1999 di Papua. Dari ujung timur Indonesia Januari Cristin $\mathrm{K}$ Yaung merupakan salah satu mahasiswi Universitas Malikussaleh Jurusan IImu Politik Fakultas IImu Sosial IImu Politik, dan juga salah satu mahasiswi dari luar Provinsi Aceh yang bersuku dan memilki kepercayaan yang berbeda dari suku dan kepercayaan di Provinsi Aceh. Januari Cristin K Yaung sendiri berasal dari ujung Timur Indonesia, Papua, yang memiliki suku santanik, dan memiliki kepercayaan Kriten Protestan.

Januari Cristin K Yaung, merupakan anak pertama dari dua bersaudara, yang memiliki ibu yang sanggat tangguh. Kedua orang tua Januari Cristin $\mathrm{K}$ Yaung telah berpisah yang kini seorang ibu yang hanya bekerja sebagai petani yang bekerja keras untuk membiayai kehidupan kedua anaknya. 
Saudara Januari Cristin K Yaung yang juga memiliki status pelajar jenjang Sekolah Menengah Pertama (SMP). Seorang ibu yang berjuang sendirian untuk membesarkan kedua anaknya yang membuat Januari ingin sekali membalas budi jasa orang ibunya, dengan membuat bangga dari hasil kerasnya ia menuntut ilmu dalam memperjuankan cita-citanya.

Januari Cristian K Yaung baru pertama kali pergi ke Aceh, dari Papua ke Aceh ia seorang sendiri, tanpa ditemani keluarga. Di Lhokseumawe ia tinggal di sebuah kos di jalan Darussalam Lhokseumawe, dan di kos tersebut ia hanya tinggal sendiri. Dengan membayar Rp. 3.000.000/tahun. Ibu kos atau ibu yang memiliki kontrakan atau kos yang ditempati oleh Janurari $\mathrm{K}$ Yaung tidak jauh dengan kos atau tempat tinggalnya.

la yang memiliki hobi berenang dan lari, dan miliki cita-cita yang kelak ia akan menjadi orang hebat yang bisa membangun dan membuat maju daerahnya, Papua. Sebelum masuk ke Perguruan Tinggi Negeri Januari Cristin K Yaung berasal dari Sekolah Mengah Atas di SMA Negeri 19 Kab. Tanggerang. Di Perguruan Tinggi Negeri Universitas Malikussaleh dengan program studi IImu Politik fakultas IImu sosial IImi Politik, melalui jalur Beasiswa Afarmasi dari Dikti (ADIK).

Januari Cristin K Yaung belajar di SMA Negeri 19 Tanggerang dan memilih Perguruan Tinggi Negeri di Universitas Malikussaleh, ia menyatakan di Papua tidak ada kendaraan untuk pergi ke sekolah. Berbeda dengan ia sekolah di Tanggerang dan di Universitas Malikussaleh yang selalu ada kendaraan umum untuk pergi ke sekolah atau pergi ke kampus. Setalah ia merasakan kuliah di Aceh, dan tinggal di Aceh, Januari merasa senang, ia merasa banyak yang sayang dengannya, ia berangapan masyarakat Aceh baik, dan menyadari bahwa Indonesia ini Bhineka Tunggal Ika, walau berbeda-beda tetap sama.

Yovita Caroline Surbakti: Gadis Karo dari Tanah Alas

Yovita Caroline Surbakti, wanita yang bermarga Surbakti yang berasal dari suku Batak Karo yang lahir 20 tahun lalu tepatnya pada tanggal 10 Januari 1998 di Bangkinang. la berasal dari Desa Lawe Desky Kecamatan Babul Makmur, Kuta Cane. Wanita yang memiliki cita-cita menjadi dosen ini memiliki hobi jalan-jalan, Travelling. Selain Jalan-jalan ia suka mencari pengalaman di tempat yang baru, dan suasana yang baru, seperti tempat di mana ia sekarang berada, yaitu di Batupat Barat, Lhokseumawe.

Di tahun 2016 Yovita Carolin Surbakti menjadi mahasiswa semester pertama di Universitas Malikussaleh. la lulus dengan jalur SNMPTN di 
Program Studi Pendidikian Fisika. Mahasiswa yang mempunyai IP 3.00, ini mempunyai banyak teman dari berbagai Program Studi dan dari program studinya sendiri, ada sebanyak 64 mahasiswa di Program Studi Pendidikan Fisika di tahun 2016. Dan sekarang di tahun 2017 Yovita sudah semester dua, dan akan memasuki semester 3 pada tahun ajaran baru. Yovita

Di Lhokseumawe ia tinggal bersama teman-temannya, di rumah kontarakan, atau rumah kos, kontrakan yang ia tempati milik salah satu warga batupat barat. Dalam satu kos Yovita tinggal bersama Fitria Andriana Simbolon dan Yulika dari mahasiswi non muslim jurusan Ilmu Administrasi Negara yang berasal dari daerah yang sama. Rumah yang ditempati Yovita berwarna biru dengan tiga kamar dengan harga sewa 2.500.000/kamar. Dalam satu kontrakan tersebut ia satu kamar dengan Fitri.

Di Lhokseumawe ia menuntut ilmu dengan mengambil program studi pendidikan fisika fakultas keguruan dan ilmu pegeahuan di Universitas Malikussaleh. la memilih program studi tersebut, karena cita-citanya yang ingin menjadi dosen. Kampus Yovita terletak di kampus utama Universitas Malikussaleh yang terletak di Gampong Reuleut. Setiap senin sampai jum'at ia pergi ke kampus dengan bus yang sudah difasilitasi oleh kampus Universitas Malikussaleh. Dengan biaya sebesar Rp. 2.000 untuk naik bus Yovita sudah sampai ke kampus.

Awal ia menjadi mahasiswi, banyak tahap-tahap yang ia lewati, sebelumnya ia hanya gadis yang pernah duduk di bangku sekolah dasar sampai ke sekolah menengah atas, ia lulus di sekolah sekolah menegah atas pada tahun 2016. Di bangku menengah atas di kelas 3 semester 2 di asal sekolahnya menawarkan untuk para murid melanjutkan pendidikan di perguruan tinggi negeri, Yovita tertarik dengan tawaran gurunya tersebut, guru yang membimbing Yovita menyarankan pilihan perguruan tinggi di luar Aceh dan di Aceh, dengan jalur SNMPTN ia memilih Universitas Sumatra Utara Medan, dan Universitas Malikussaleh Lhokseumawe, pilihan pertamanya USU tidak lulus, dan pilihan keduanya di Universitas Malikussaleh Aceh lulus, karena tekat ia untuk kuliah ia melanjutkan untuk mendaftar ulang di Unimal. Awal ia mendaftar ulang ia berangkat dari kampung halaman ke Lhokseumawe bersama teman-temannya, yang juga satu daerah dan satu Universitas, ketika ia dan teman-teman sampai ke Lhokseumawe untuk mendaftar ulang ia dibantu atau diarahkan oleh abang/kakak leting. Setalah mendaftar ulang, ia menunggu untuk jadwal kuliah dihari pertama menjadi mahasiswi. 
Setelah tinggal atau merantau di Lhokseumawe Aceh, yang baru menjalani 1 tahun di negeri orang sebagai pendatang, belum banyak yang pengalaman yang didapatkan. Kegiatannya sehari-hari hanya dihabiskan untuk kuliah, membuat tugas, selebihnya ia gunakan untuk menonton menggunkan leptop, bermain permainan yang disediakan di aplikasi handphone, dan bermain berkumpul bersaa teman di lingkungan tempat tingglnya, dan beribadah. Walaupun baru menjalani satu tahun hidup di daerah yang berbeda budaya, tetapi ia mulai mengikuti aturan, atau kebiasaan yang dilakukan di tempat perantauannya, atau daerah Syari'ah Islam, ia mendapatkan perbedaan yang belum didapatkan di daerah asalnya, seperti menjaga waktu, atau dapat mengatur waktu karena aturan yang ditetapkan di daerah perantauan, mengatur busana yanag lebih sopan, merasakan dan menikmati masakan khas daerah Aceh.

\section{Pengalaman Mahasiswa Non Muslim dalam Beradaptasi di Aceh}

Dari pengalaman beradaptasi mahasiswi non muslim awalnya mereka mengungkapkan ada perasaan takut sebelum menetap di daerah perantauan Lhokseumawe, Aceh. Rasa takut tersebut beragam, mereka berpendapat di Aceh rawan konfilk, takut karena berbeda. Karena hal-hal yang demikian yang membuat perasaan mereka takut tinggal atau kuliah di Aceh. Mahasiswi non muslim awalnya melihat Aceh atau Universitas Malikussaleh dari sosial media atau melihat dari google. Mereka mencari tahu tentang Lhokseumawe, dikarenakan belum banyak pengetahuan tentang Universitas Malikussaleh.

Mahasiswi non muslim memiliki marga atau yang bersuku Batak. Setiap marga yang sama dengan mereka, mereka mengakuinya saudara, tidak hanya marga yang sama, perkumpulan sesama suku mahasiswa non muslim menganggap seperti keluarga baru yang dimilikinya di Lhokseumawe. Di Lhokseumawe kakak/abang leting yang membantu mereka bukan hanya mereka akui sebagai senior, tetapi juga meraka akui sebagi saudara yang sama-sama berjuang untuk hidup di daerah perantauan dengan suasana berbeda, budaya berbeda, dan kepercayaan yang berbeda pula. Saudara-saudara atau senior-senior mereka yang berada di Lhokseumawe, yang membimbing mahasiswa non muslim awal masuk ke perguruan tinggi dan menetap di daerah Syari'ah Islam.

Mahasiswi non muslim yang berasal dari Papua, berbeda dengan mahasiwi non muslim yang bersuku Batak. Jika diawal kuliah mahasiswi non muslim dari suku Batak memiliki saudara dengan sesuku mereka, Sebaliknya mahasiswi non muslim dari Papua, menganggap semua sama, 
Indonesia Bhineka Tungga lka, walau berbeda-beda tetapi tetap sama. Mereka melangkah ke Aceh dengan keyakinan sendiri, tidak ada yang mendampingi. Sesampai di Aceh pun mereka berusaha sendiri, dengan perlahan-lahan mereka mendapatkan saudara atau teman baru di Aceh.

Mahasiswi non muslim yang bersuku Batak, biasanya tinggal berdekatan atau tinggal satu rumah bersama-sama. Mereka tinggal di lingkungan yang sama di Batuphat. Mereka melakukan hal tersebut agar rasa kebersamaan tetap terjaga. Berbeda dengan mahasiwi yang berasal dari Papua, mahasiswi yang wanita lebih memilih tingggal sendiri di ebuah kontrakan di Kota Lhokseumawe, dan mahasiswa yang laki-laki memilih tinggal di sekret di lingkungan kampus Bukit Indah, bersama teman-teman yang berbeda lainnya. Namun, mahsiswi non muslim yang berasal Papua yang tinggal di Kota Lhokseumawe, juga sering berkumpul di sekret BEM kampus Bukit Indah dengan teman-temannya yang berasal dari daerah bersama, tidak hanya berkumpul dengan teman-temannya.

Tugas mahasiswi non muslim untuk beradaptasi adalah dua kali lipat beratnya dibandingkan mahasiswi yang beragama Islam atau mahasiswi yang tidak merantau. Kalau mahasiswi yang tidak merantau hanya perlu beradaptasi dengan lingkungan kampus baru dan teman-teman di kampus, maka tidak dengan mahasiswi non muslim. Mahasiswi non muslim memiliki tanggung jawab yang berlipat ganda yaitu untuk beradaptasi dengan lingkungan kampus barunya dan beradaptasi dengan lingkungan tempat tinggalnya yang baru. Seorang mahasiswi non muslim memiliki kebiasaan dan kebudayaan yang berbeda dengan orang-orang yang tinggal di tempat rantaunya.

Dari aspek sukanya, mahasiswi non muslim Universitas Malikussaleh, lebih banyak mendapatkan pengalaman dari mahasiswa non muslim yang bersuku Batak Meraka berpendapat bahwa sukanya tingggal di tempat perantauan yang saat ini karena ada saudara dari suku yang sama, dapat berkumpul bersama, walau mereka merasa asing di daerah Syari'ah Islam. Selain dapat berkumpul dengan saudara baru mahasiswi non muslim yang bersuku batak meraka merasa banyak orang-orang yang cepat kenal dengan mereka, seperti di dalam kelas antara dosen dan mahasiswi non muslim Universitas Malikussaleh.

Upaya yang dilakukan mahasiswi non Muslim dalam berdaptasi di Aceh melalui agama dan budaya yang berbeda dalam menjalani pengalaman yang mahasiswi non muslim bayangkan tentang Aceh, informasi tentang 
aceh, tanggapan keluarga tentang pilihan di Aceh, arahan tentang Aceh setelah sampai di Aceh, memilih tempat tingggal di Aceh, kebiasaan mahasiswi yang dilakukan di Aceh, hambatan mahasiswa dalam berinteraksi di lingkungan sekitar. Dalam hal seperti ini yang disampaikan Januari Cristin K. Yaung Mahasiswi Jurusan IImu Politik Fakultas IImu Sosial IImu Politik kepada peneliti tentang hal tersebut:

“... Gambaran liat di Internet awal datang ke Aceh ada rasa takut, karena sendiri juga, dan masi pertama kali juga. Tanggapan keluarga, mama dukung aja karena mama juga udah sering jauh dari saya. Gak ada yang di hungungi kak, datang-datang aja, tanya sama orang. Kalau kebisaan di Aceh, ke kampus aja, sering main ke secret BEM, kerjakan tugas. Hambatanya bahasa aja kak" (Wawancara, 25 April 2017).

Hal yang sama disampaikan oleh Fitri Andriana Simbolon Jurusan IImu Adminitrasi Negara Fakultas IImu Sosial IImu Politik kepada peneliti:

“... Awalnya saya bayangkan, Aceh dekat laut kayaknya indah, cantik karena di kampung jauh, awal mau masuk atau kuliah, bingung mau masuk mana, terus kayaknya Unimal tidak jauh juga dengan Medan, yaudah terus pilih Unimal aja, terus seelah itu liat-liat Google. Awal datang ke Unimal yang dihubungi Abang leting yang ada disini, setelah sampai di Aceh kami dicari tempat kos sama abang, kakak leting. Kebiasaan ya ke kampus, ke gereja, jarang keluar rumash sih kak, kalau di kos main, atau nonton. Hambatan, bahasa kak, terkadang gak megerting apa yang di bahas sama kawan-kawan orang Aceh" (Wawancara, 25 April 2017).

Hal yang sama disampaikan oleh Yovita Caroline Surbakti mahasiswi Jurusan Pendidikan Fisika Fakultas IImu Keguruan dan Penddikan kepada peneliti:

“... Gambaran gak ada kak, dukungan dari guru juga, pilihan dari guru ambil univeritas di Aceh, terus ya pilih Unimal cuma dengar-dengar Aceh banyak GAM, tempat konflik, sebelum ke Lhokseumawe takut, terus dapat dukungan dari mama (gada lagi konflik, udah aman) terus mama pun dukung kuliah di Lhokseumawe, biar gak terlalu bebas, ada waktuwakttunya keluar, kalau kuliah di Medan, mama khawatir terlalu bebas. Di Lhokseumawe ada kakak/abang leting, hubungi mereka, awalnya tinggal bersama mereka, terus mereka yang cari kos untuk kami. Kebiasaan kami disini, ke kampus, nonton film, belajar, main di kos, kumpul-kumpul di rumah tetangga, olahraga jarang, ke gereja. Hambatannya sering ada 
ibu-ibu yang litanya kayak gak suka, kalau mau tegur jadi segan, di kampus juga terkadang kaya gitu' (Wawancara, 25 Apil 2017).

Lebih lanjut disampaikan oleh Lastri Sirait Mahasiswi Jurusan Manajemen Fakultas Ekonomi kepada peneliti:

“... Ada, lewat di Unimal dari jaun SNMPTN, dulu sih sebelum ke Aceh banyak yang bilang, Aceh kan dulu rawan konflik tempat Syari'at Islam, mau tinggal di Aceh karena ada kakak disini yaudah coba disini aja (Aceh). Orang tua boleh-bolehi aja Yang di hubungi kakak, ada kakak juga yang kulih di sini. Disini tinggal sama kakak, tinggal di rumah kakak, karena yang punya kos kakak juga. Kebiasaan disini ya, kuliah, nonton film, kumpul-kumpul kawan, main ludo, ke geraja juga. Hambatannya, gada karena udah lama juga dini, tinggal disini pun senang gak senang ya dijalani aja" (Wawancara, 25 Apri 2017).

Lalu disampaikan oleh Yulika Lumban Tobing mahasisiwi jurusan IImu Adminitrasi Negara Fakultas IImu Sosial Ilmu Politik kepada peneliti:

“... Gambaran gak ada kak, datang-datang aja, gak tau sebelumnya Lhokseumawe tu kayak mana, kirai besar kayak di Medan, ternyata enggak, pertama kali yang memberi tau tentang Lhokseumawe guru, karena dari sekolah memang disuru ambil Universitas yang di Aceh, tanggapan dari orang tua, awalnya sempat adu mulut dengan abang, gak boleh kuliah di Aceh, harus jadi aparat aja, kalau mama setuju aku kuliah, terus cara negahinya ada opung yang bilang ke abang, jadinya abang setuju. Sesampai di Aceh aku ada kakak leting, aku hubungi kakak leting, terus aku nginap di rumahnya, yang cari kos juga kakak leting. Kalau kebiasaan kami di disini seperti biasa, jarang sih kak keluar, paling ke kampus, di kos kumpul kawan, nonton film, ke gereja, belajar gitu lah kak, hambatannya, awalnya sedih tinggal di sini, karena ada kawan juga yang seiman, udah mulai terbiasa" (Wawancara, 12 mei 2017).

\section{Ragam Strategi Adaptasi Mahasiswa non Muslim}

Mahasiswi non muslim melakukan aktifitas di lingkungan kampus dan lingkungan tempat tinggal, mereka melakukan adaptasi di dalam linkungan yang mayoritas beragama Islam. Di lingkungan kampus sebagian mahasiswi non muslim mengikut organisasi yang dibentuk di kampus, meraka melalakuan seperti apa yang orang lain lakukan, mereka lebih sering mengikuti atau menjalani visi-misi organisasi yang mereka jalani. Selain berperan dalam oraganisasi, mahasiswi non muslim mengikuti kelas dan 
mata kuliah setiap jadwal kuliahnya, mereka mengisi suasana dalam kelas dengan mendengarkan, memperhatikan, tanya jawab, dan mempresetasikan hasil dari tugas yang ia kerjakan individu maupun kelompok kepada dosen.

Selain di dalam kelas, mahasiswi non muslim mengisi waktu kosongnya setelah jam atau mata kuliahnya selesai, waktu kosong mereka biasanya digunakan untuk berdiskusi dengan sesama teman kelas, atau teman dari berbeda budaya dan agama, mahasiswi non muslim dan teman-teman berbeda budaya juga sering bercanda satu sama lain, dalam sebuah keakraban mahasiswi non muslim tidak ada hal menyebabkan proses pergaulan mahasiswa non muslim. Dengan proses saling menyapa, senyum, saling menghargai, mahasiswa non muslim tidak merasa terasing, walau ia minoritas di dalam kelas atau di dalam lingkungan kampus.

Di lingkungan tempat tinggal mahasiswi non muslim bermayoritas beragama Islam, mahasiwi non muslim tinggal bekelompok, mereka tingal dengan rumah yang berdekatan satu sama lain, mereka tinggal dilinkungan yang sama di Bathupat Barat, Lhokseumawe. Dengan ikatan persaudaraan mereka tersebut, membuat mereka nyaman tinggal di tempat dengan lingkungan yang bermayoritas beragama Islam. mereka sering bertegur sapa dengan warga sekitar, walaupun terkadan ada sebagaian tetanga yang melihat mereka dengan paras muka yang tidak enak. Tetapi walaupun begitu mereka hargai karena mereka hanya menumpang hidup di daerah perantauan. Aktivitas-akktivitas yang mereka lakukakn di lingkungan tempat tinggal, aktivitas tersebut dilakukan mahasiswi non muslim sangat terbatas, mereka sepulang dari kampus, berdiam di kos, atau rumah yang mereka tempati. Di kos mereka melakukan pekerjaan sehari-hari, mengerjakan tugas yan diberi dosen, bermain game yang tersedia di aplikasi handphone, menonton film drama dengan leptop dan bercanda dengan teman-teman kos. Selain kebiasaan umum tersebut yang dilakukan oleh mahasiswi non muslim di kos, mahasiswi non muslim bergaul dengan teman-teman di rumah-rumah kos yang lain untuk membuang kejenuhan, mereka sering berkumpul dengan mahasiswi seiman di lingkungan tempat tinggal mereka, biasanya mereka berkumpul untuk bercanda, berbagi motivasi, menceritakan kesedihan atau kesenagan, dan bermain gitar atau bernyayi bersama.

Mereka berkumpul dengan perempuan atau laki-laki dirumah yang mempunyai awasan dari orang tua, atau ibu kos. Jika berkumpul untuk bermain gitar di malam hari, mereka bermain dengan suara kecil, agar tidak 
terganggu dengan masyarakat sekitarnya, mereka berkumpul hanya sampai jam 22.00 wib, mereka melakukan itu karena larangan, atau peraturan dari Gampong yang mereka diami, tidak hanya bermain gitar atau bernyayi, untuk sesutu di luar rumah atau berkumpul meraka harus sudah di rumah atau di kos masing-masing pada jam 22.00 wib.

Selain barmain, belajar, mahasiswi non muslim melaksanakan ibadah setiap hari minggunya di komplek arun , atau di gedung arun PJKP, dalam dua minggu dalam sebulan mereka ada membuat ibadah wajib bagi para mahasiswa untuk hadir dalam acara rohani atau beribadah di gedun PJKP arun. Mereka beribadah dengan berpakain sopan mengenakan rok untuk yang wanita, dan mengunakan kemeja untuk yang laki-laki. Dalam ibadah mereka di bimbing oleh ibu Itjen Tari yan berdiam di komplek PIM Lhokseunawe.

Pada bulan mai lalu mereka membuat acara yang diselenggarakan oleh Himpuanan Mahasiswa Kristen Lhokseumawe, yang diketuai oleh Jansen Girsang. Meraka membuat acara olahraga dengan nama Sport 2, diacara tersebut mereka membuat lomba antar sesama meraka, seperti lomba sepak bola, badminton, volly, acara tersebut dilaksanakan selama 2 hari. Meraka melaksanakan acara Sport yang dibentuk HMKL untuk membuat tali persaudaraan mereka menjadi lebih erat, dan saling kompak. Tidak hanya mahasiswa yang himpunan mahasiswa Kristen Lhokseumawe, tetapi merka juga mengundang mahasiswa yang berada di Langsa, dan Banda Aceh, mereka berkumpul untuk memeriahkan acara dan untuk bersilahturahmi dengan sesama kerabat dan semasama mahasiswa Kristen di perantauan.

Dalam proses adaptasi dan strategi adaptasi mahasiswi non muslim mengalami hamaban-hamabatan dalam beradaptasi, seperti berbedanya aturan dari daerah asal dan di daerah Syari'ah. Aturan-aturan yan mereka jalani hanya menghargai yang dilakukan oleh masyarakat sekitar. Mereka yang biasayanya di daerah asal dengan peraturan yang tidak terlalau ketat, dapat melakukan sesuatu dengan banyak hal, dapat melakukan adaptasi dengan mudah tanpa rasa cangung. Dengan tinggal di Lhokseumawe, harus mengurangi aktivitas, atau berhati-hati dalam melakukan adaptasi di luar lingkungan tempat tinggal dan kampus. Tidak sedikit, sindiran, tatapan sinis dari warga sekitar, mahasiswa dikampus, dosen, yang tidak suka dengan perbedaan mahasiswa non muslim. Hal-hal tersebut ia jalani sepenuh hati untuk mencapai keinginnya dan pilihannya. 
Dalam menyesuikan diri dengan kehidupan masyarakat Lhokseumawe, dalam aspek bahasa, makanan, tempat tinggal dan pakaian di Aceh, meraka mulai terbiasa atau menjalani karena memang wajib dijalani. Dari segi beradptasi dari segi bahasa, mahasiswi non muslim tidak menguasai bahasa daerah Aceh, mahasiwi semester dua atau mahasiwi yang baru satu tahun tinggal di lingkungan yang menggunakan bahasa daerah aceh, dalam bentuk bahasa mahasiswi non muslim sudah belajar kata-demi kata dalam bahasa aceh, untuk menambah wawasan dan mudah dalam beradaptasi. Dalam bahasa sendiri mahasiswi non muslim mengunakan bahasa Indonesia dalam berinteraksi di lingkungan sekitar dan di dalam lingkungan kampus.

Dalam bentuk makanan, mahasiswi non muslim mempercayai ibu kos atau jasa katering untuk kebutuhan lauk pauk mereka. Sebagian mahasiswi awalnya tidak suka dengan makanan khas Aceh yang disajikan oleh pemilik katering, dengan lidah yang belum terbiasa dengan masakan Aceh, mereka merasakan aneh pada masakan Aceh, dengan seirinnya waktu dan masakan yang setiap harinya dirasakan, mahasiswi non muslim menjadi suka dan menikmati masakan Aceh yang disebut plik $U$ atau patarana. Mahasiswi non muslim juga sering meminta masakan yang disukainya. Sebagaian mahasiswa ada yang sama sekali tidak suka dengan masakan Aceh, atau makanan khas Aceh yang bernama plik, ia selalu makan dengan makanan yang ia suka saja. Kebiasaan mereka selalu berkompromi dengan ibu yang memasak katering sayur atau masakan apa saja yang mereka suka dan meka tidak suka.

Mahasiswi non muslim berkumpul di Batuphat Barat Lhokseumawe dengan suasana yang strategis. Dengan tempat tinggal atau lingkungan yang mereka tempati, mereka menjalaninya dengan rasa nyaman, walaupun dalam keadaan terpaksa. Keadaan nyaman mereka kerena mereka tinggal dengan kelompok mereka seiman, dengan adanya teman seperjuangan mereka harus tetap betah tinggal di daerah Syari'ah Islam. Berbeda dengan deerah asal mereka yang tidak terlalu berat pertauran untuk tinggal dan beradaptasi. Dalam hal berpakain sangat berpengaruh di tempat tinggal mereka sekarang, mereka berpakaian tidak seperti biasa ketika mereka di daerah asal mereka, dengan peraturan yang ada di lingkungan atau tepat tinggal mereka sekarang, mereka berpakaian dengan sopan, dan tertutup.

Pakaian tertutup dikenakan mahasisiwi non muslim dikenakan mahasiswi non muslim di lingkungan kampus dan lingkungan tempat tinggal. Pakaian 
yang mereka pakai tidak seperti orang Islam, yang mengenakan jilbab jika keluar dari rumah, mereka hanya mengenakan celana yang panjang atau baju setengah lengah. Pakaian-pakaian yang menurut mereka tidak bisa dipakai di Aceh, mereka tidak membawanya dari daerah asal, mereka hanya membawa pakaian yang menurut mereka pantas dikenakan di daerah Sya'riah Islam. Mahasiswa non muslim mengenakan pakaian atau celana pendek jika hanya beraktifitas di dalam kos.

Mahasiswi non muslim setuju dengan peraturan-peraturan yang diberlakukan di Aceh, Lhokseumawe. Mereka menganggap agar mereka menjadi seseorang yang lebih baik lagi, menjadi seorang yang menghargai waktu, menjadi seseorang yang disiplin. Tinggal dengan menjadi mahasiswi perantaaun menjadikan mereka mahasiswi yang mandiri, mengerti banyak hal, dan dapat meghargai dengan sesorang yang berbeda.

\section{Penutup}

Mahasiswi non Muslim beradaptasi dengan lingkungan sekitar, dan tetap melakukan kebiasaan-kebiasaan, praktik-praktik dan terdisi-tradisi mereka, di tempat baru mereka berdaptasi, agar tetap terjaga kebudayaan mereka. Mahasiswi non Muslim melakukan penyesuaian diri, dengan menghormati keyakinan dari budaya lain. dalam hal ini mahasiswi non Muslim berpakain sopan seperti aturan yang di lihatnya. Atauran yang berbeda dari budaya asal mahasiswi non Muslim. Mahasiswi non Muslim menimbulkan perbedaan yang siknifikan dari segi ajaran agama dalam berbusana terlihat perempuan dari mahssiwi non Muslim tanpa menggunakan hijab dalam norma agama mereka. Mahasiwi non Muslim menyatakan aspek yang dirindukan salah satunya makanan khas daerah meraka, atau makanan orang tua mereka. Dalam pengalaman-pengalaman litas budaya, mahasiswi non Muslimm mulai terbiasa, atau sudah terbiasa hidup dengan perbedaan. Mahasiswi non Muslim menjalani perlahn-lahan hubungan terhadap perbedaan, dan saling meghargai sesamanya. Mahasiwa non muslim melakukan penyesuaian diri di tempat yang baru, mahasiwi non Muslim tetap bertahan di lingkungan baru walau banyak rintangan dan tantang. Mahsiswi non muslim melakukan cara saling bertegus sapa dengan masyarakat, agar hubungan mereka terjaga dengan baik.

\section{Daftar Pustaka}

Agus, Bustanuddin, 2006, Agama dalam Kehidupan Manusia Pengantar Antropologi Agama, Jakarta PT Raja Grafindo Persada 
Abdullah, Irwan, 2006 Kontruksi dan Reproduksi Kebudayaan, Yogyakarta:Pustaka Belajar.

Hadi Amirul, 2010 Aceh Sejarah dan Tradisi, Jakarta: Yayasan Obor Indonesia

Koejaranigrat, 2013, Pengantar IImu Antropologi, Jakarta: Rineka ( Cipta)

Mulyana, Deddy, 2005 Komunikasi Antar Budaya, Bandung: PT Remaja Rosdakarya

Soekanto, Soejono, 2012, Sosiologi Suatu Pengantar, Jakarta: Rajagrafindo Persana Ujan, 2011, Multikulturalisme, Jakarta: Indeks

Usman, Rani, 2009, Enis Cina Perantauan di Aceh, Jakarta: Yayasan Obor Indonesia

Pelly Usman, 2013 Urbanisasi dan Adaptasi, Medan: Unimed Press

Moleong, 2005, Metode Peneltian Kualitatif, Bandung: Rosda

Mosse, Julia Celves, 2007, Gender dan Pembangunan, Yogyakarta:Pustaka Pelajar

Skripsi

Andri, Delfi, 2015, Komunikasi Antar Budaya etnis Batak, Jurusan Kmunikasi, Universitas Malikussaleh Jurnal Skripsi

Ayu, Mempuni, Restu, 2015, Memahami Adaptasi Budaya pada Pelajar Indonesia yang Sedang Belajar di Luar Negeri, jurusan ilmu sosial ilmu politik, Universitas Diponogoro

Internet

Agus-Salam Rahmat/penegertian-perguruan_tinggi. Pdf Dikses September 2016

http: rescrc.upi.edu/operator/t_bp_0808290_chapter1pdf.Diakses 15 September 2016 